\title{
Assessment of natural groundwater physico-chemical properties in major industrial and residential locations of Lagos metropolis
}

\author{
Lekan Taofeek Popoola $^{1}$ (1) $\cdot$ Adeyinka Sikiru Yusuff $^{1} \cdot$ Tajudeen Adejare Aderibigbe $^{2}$
}

Received: 11 December 2018 / Accepted: 10 October 2019 / Published online: 17 October 2019

(c) The Author(s) 2019

\begin{abstract}
This study investigated groundwater quality collected from two industrial and residential locations in each of Lagos metropolis. Prescribed standard procedures of American Public Health Association were used to measure physico-chemical parameters of each of the groundwater samples which include $\mathrm{pH}, \mathrm{EC}$, DO, TDS, $\mathrm{BOD}, \mathrm{COD}$, anions $\left(\mathrm{Cl}^{-}, \mathrm{NO}_{3}{ }^{-}, \mathrm{SO}_{4}{ }^{2-}, \mathrm{PO}_{4}{ }^{3-}\right)$ and heavy metals $(\mathrm{Cu}, \mathrm{Zn}, \mathrm{Pb}, \mathrm{Mn}, \mathrm{Fe}, \mathrm{Co}, \mathrm{Cd}$ and $\mathrm{Cr}$ ). From laboratory analysis, measured physico-chemical parameters were within the permissible ranges specified by the WHO and NSDWQ except $\mathrm{pH}, \mathrm{TDS}, \mathrm{EC}, \mathrm{Pb}, \mathrm{Mn}$ and Fe for groundwater samples from industrial locations and $\mathrm{pH}, \mathrm{Pb}, \mathrm{Mn}$ and $\mathrm{Fe}$ for residential locations. Higher concentrations of TDS and $\mathrm{EC}$ reported for groundwater samples from industrial locations were attributed to heavy discharge of effluents from industrial treatment plants as well as dissolution of ionic heavy metals from industrial activities of heavy machines. Statistical Pearson's correlation revealed physico-chemical parameters of water quality to be moderately and strongly correlated with one another at either $p<0.05$ or $<0.01$.
\end{abstract}

Keywords Groundwater $\cdot$ Physico-chemical $\cdot$ Heavy metals $\cdot$ Anions $\cdot$ Water quality

\section{Introduction}

Lagos has been identified as the most populous mega-city in Nigeria controlling $40 \%$ of the country's industrial and manufacturing activities contributing 8000 tons of hazardous waste per year into the environment (Adewolu et al. 2009). Due to these attributes, enormous waste effluents are being generated on an hourly basis through industrial and residential activities with higher demand for domestic water consumption linked to her densely populated instinct. However, natural groundwater contamination occurred due to transportation of toxic and hazardous materials resulting from residential and industrial activities via leaching into underground within Lagos metropolis. This posed alarming health hazards to Lagos habitants whose major source of water supply for domestic purposes comes from underground water.

Lekan Taofeek Popoola

popoolalekantaofeek@yahoo.com

1 Unit Operation and Material Science Laboratory, Department of Chemical and Petroleum Engineering, Afe Babalola University, Ado-Ekiti, Ekiti State, Nigeria

2 Science Laboratory Technology Department, Yaba College of Technology, Yaba, Lagos State, Nigeria
Thus, assessment of groundwater quality based on health and safety regulations specification before domestic use is highly imperative. Many laboratory procedures and tools involving parameters evaluation of groundwater assessment such as $\mathrm{pH}$, acidity, temperature, salinity, turbidity, alkalinity, electrical conductivity, total soluble solids (TSS), total dissolved solids (TDS), biological oxygen demand (BOD), chemical oxygen demand (COD), dissolved oxygen (DO) and heavy metal concentration have been applied (Edwin et al. 2015; Rahmanian et al. 2015; Dissmeyer 2000). It is believed that estimated parameters with concentrations higher than those specify by the World Health Organization (WHO) and other health regulatory bodies suggest poor drinking water quality (WHO 2011). This great challenge has motivated researchers and governmental agencies around the globe to engage in series of investigations (Tuzen and Soylak 2006; Heydari and Bidgoli 2012).

Many laboratory analytical techniques such as inductively coupled plasma and mass spectrometry (ICP-MS) (Faisal et al. 2014), flame atomic absorption spectrometry (FAAS) (Behailu et al. 2017), direct extraction/air acetylene flame method (Rahmanian et al. 2015) and graphite furnace atomic absorption spectrophotometer (AASGF) (Mkadmi et al. 2018) had been applied to evaluate 
concentrations of heavy metals in groundwater samples with different statistical analytical tools such as principal component analysis (PCA) (Faisal et al. 2014; Duan et al. 2015), statistical package for social scientists (SPSS) (Lovelyn et al. 2014), analysis of variance (ANOVA) (Edwin et al. 2015), least significance difference (LSD) (Sabhapandit et al. 2010) and single factor analysis of variance ( $t$ test) (Shigut et al. 2017) to analyse the results.

Groundwater is the major source of drinking water in Lagos metropolis due to high disposal of wastes in different forms into water bodies enhanced by her densely populated feature, thereby contaminating other water sources. However, waste effluents from industrial treatment plants and solid wastes from residential areas find their ways into groundwater via leaching. Thus, groundwater quality must be regularly monitored in these locations. In this study, groundwater samples were obtained from prominent industrial and residential locations of Lagos State, Nigeria, and were evaluated to know the concentration of heavy metals (copper, zinc, lead, manganese, iron, cobalt, cadmium and chromium) that are present and other physico-chemical properties such as total dissolved solid, $\mathrm{pH}$, electrical conductivity, chemical oxygen demand, biological oxygen demand, chloride, nitrate and sulphate (Mohsin et al. 2013). The obtained values were compared with standard values set by the Nigerian Standard for Drinking Water Quality (NSDWQ) and the World Health Organization (WHO) guidelines to ensure high water quality before drinking and other domestic purposes. Statistical Pearson's correlation was used to check the level of correlation of physico-chemical parameters at $p<0.05$ or $<0.01$ in groundwater samples collected from examined locations.

\section{Materials and methods}

\section{Study area}

Lagos has been known as the largest and most populous city in Nigeria with a population of 17.5 million (Adewolu et al. 2009). It lies on the geographical coordinates of $6^{\circ} 27^{\prime} 11^{\prime \prime} \mathrm{N}$, $3^{\circ} 23^{\prime} 44^{\prime \prime} \mathrm{E}$ with $22 \%$ of its $3577 \mathrm{~km}^{2}$ to be lagoons and creeks. Lagos has 29 industrial estates and 4 central business districts attributed with 26.7\% Gross Domestic Product (GDP) out of Nigeria's total GDP. It has the highest emission level of 8000 tons of hazardous waste yearly, most of which is directly discharged into the Lagos lagoon (Adewolu et al. 2009).

The case study areas (shown in Fig. 1) are Deli Foods Nigeria limited, located along Apapa-Oshodi (an industrial centre known with many manufacturing activities) and $\mathrm{OK}$ Foods, located at Ladipo in Mushin area of Lagos whose major productions are biscuits and confectioneries. Oshodi and Agege community boreholes were chosen as sites for residential groundwater collection. The aquifer in all the study areas was characterized as unconfined under saturated zone which is coastal plain sand comprising of silt, clay and sand (Akinlalu and Afolabi 2018), while the respective borehole depths for Deli foods, OK foods, Oshodi and Agege community boreholes were 117, 134, 109 and $143 \mathrm{~m}$ (LSWRC 2018).
Fig. 1 Map of Lagos showing sample locations

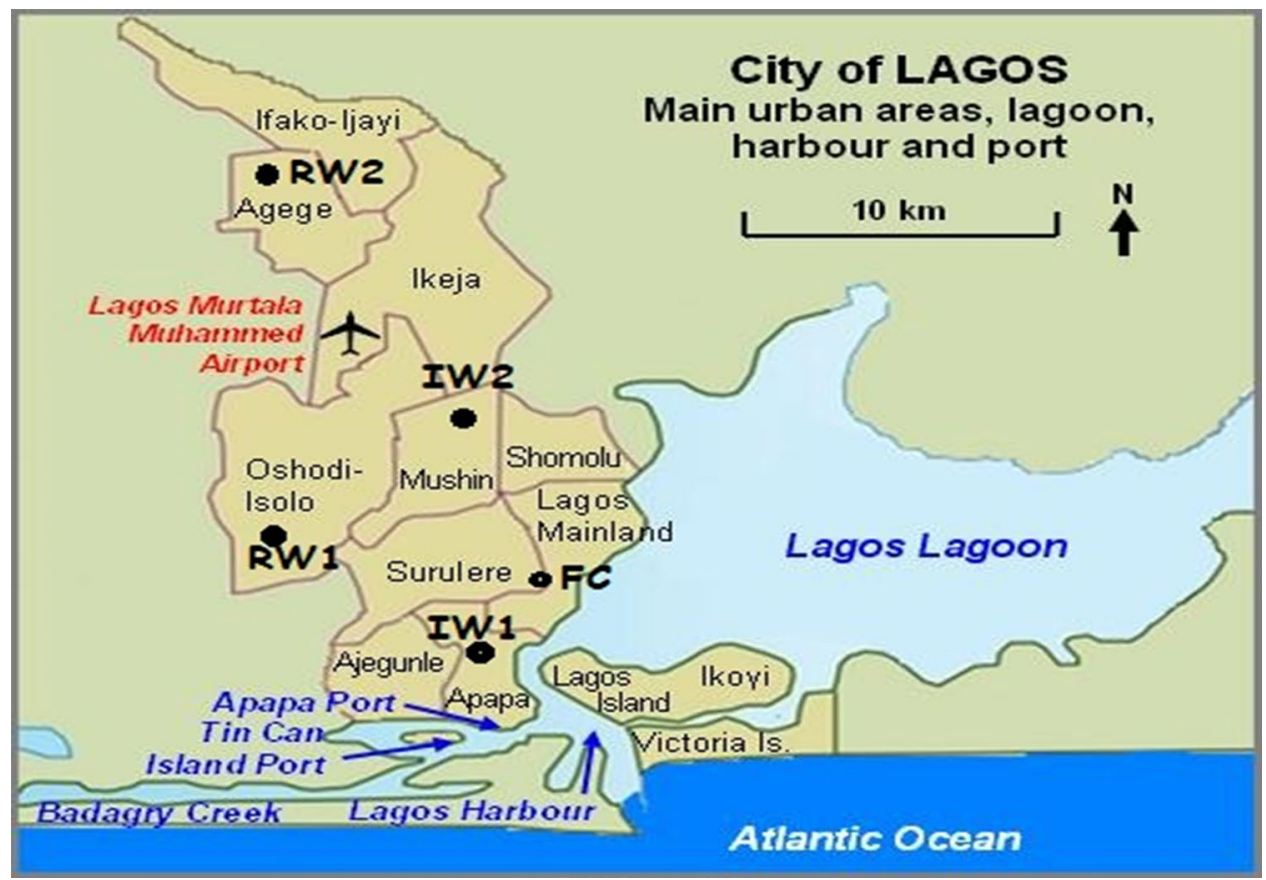




\section{Samples collection}

Two litres of groundwater samples were collected from boreholes of Deli foods (IW1) and OK foods (IW2). Also, groundwater samples were collected from Oshodi and Agege community boreholes, each located $40 \mathrm{~km}$ away from Deli foods (RW1) and OK foods (RW2), respectively. A total of four samples were collected from the locations. This sample collection exercise was done during rainy season (May 2018), and samples were kept in 5-L-capacity plastic kegs rinsed with hexane and distilled water in the laboratory to remove impurities that may be present before collection. The kegs were instantly covered with aluminium foil and lids sealed to avoid interference with atmospheric contaminants. Sample bottles were adequately labelled after which samples were analysed for different physico-chemical properties.

\section{Materials and methodology}

All chemicals and reagents (sodium hydroxide, distilled water, buffer solution, indicators, silver nitrate, sodium trioxocarbonate IV, ethylenediamminetetraacetic acid (EDTA), bleaching powder, potassium iodide, sodium thiosulphate solution, manganese sulphate and hydrochloric acid used for laboratory analysis were of analytical grade and purchased from TopJ Scientific in Ado-Ekiti, Ekiti State, Nigeria. Laboratory analysis was conducted inside the waste water treatment laboratory of Afe Babalola University, Ado-Ekiti, Ekiti state.

Samples' pH was measured using OAKION pH metre (S/N 2202625, Eutech Instruments, Singapore). Electrical conductivity (EC), dissolved oxygen (DO) and total dissolved solid (TDS) were calculated by electrometric method. Salinity was determined using ion exchange electrode method (Atekwanaa et al. 2004). Calcium present was determined using EDTA method. Iron was determined using Hach method 8008 (Ferro Ver). Nitrate, sulphate and chemical oxygen demand (COD) were determined using colorimetric method with HACH standards/methods 8039 high range, 8051, 8190 and 8155 low range, respectively. Colorimetric salicylate method (HACH method 8155 Low Range) was used to calculate ammonia present. Biological oxygen demand (BOD) was determined using azide modification method (5210A) prescribed by American Public Health Association (APHA 2012). Chloride content was determined using argentometric method, while heavy metals concentrations were calculated using flame absorption spectrophotometer (Buck Scientific AAS VGP 210 model). All parameters were measured in $\mathrm{mg} / \mathrm{L}$ with the exception of EC measured in $\mu \mathrm{S} / \mathrm{cm}$ while $\mathrm{pH}$ was unitless. Analysis of variance (ANOVA) was the statistical tool used together with computer SPSS 16.0 windows application.

\section{Results and discussion}

Each of the samples collected was analysed for 23 physicochemical properties, namely $\mathrm{pH}, \mathrm{EC}, \mathrm{DO}$, TDS, BOD, COD, nitrate, chloride, sulphate, solids salinity, ammonia and heavy metals which include chromium, nickel, cadmium, lead, cobalt, mercury, copper, zinc, vanadium, manganese and iron. Table 1 presents the laboratory results of all examined physico-chemical properties as compared with values from the existing studies.

\section{pH}

The $\mathrm{pH}$ values for water samples obtained for IW1, IW2, RW1 and RW2 were $7.58 \pm 0.06,8.31 \pm 0.02,6.35 \pm 0.15$ and $6.46 \pm 0.05$, respectively, as shown in Table 1 . The industrial water sample (IW2) was alkaline, while residential borehole water samples (RW1 and RW2) were slightly acidic and values were not within the permissible range (6.5-8.0), specified by the Nigerian Standard for Drinking Water Quality (NSDWQ) (SON 2007) and the World Health Organization (WHO 2009). The alkalinity of water sample (IW2) may be attributed to the presence of bicarbonates (part of essential raw materials for production) lost into the soil and percolated into the underground soil via rain water. Also, biological degradation of waste in the soil may be a major influence of this observation. Slightly acidic nature of RW1 and RW2 may result from carbonic acid deposit formed via reaction of carbon dioxide with rain water (Tiwari et al. 2015). This may be transported from soil surface level to form deposits in the groundwater via some chemical processes over a period of time. Water with high alkalinity has proven to cause swelling of hair fibres and gastrointestinal irritation (Rose 1986). Acidic water has been identified to cause damage to cells of mucous membrane, eyes and skin irritation (WHO 1986; Meinhardt 2006). Also, acidic water contributes majorly to corrosion of metals coupled with disinfection efficiency causing indirect effect on human health.

\section{Total dissolved solids (TDS) and electrical conductivity (EC)}

The respective TDS obtained for samples IW1, IW2, RW1 and RW2 were 559.2, 589.7, 319.5 and $247.5 \mathrm{mg} / \mathrm{L}$, as shown in Table 1. Only water samples located within industries (IW1 and IW2) revealed maximum TDS values higher than the permissible value $(500 \mathrm{mg} / \mathrm{L})$ of the NSDWQ and the WHO. Minimum variation below permissible value was exhibited by RW1 and RW2. Maximum TDS exhibited by IW1 and IW2 is an indication of saline water which may be attributed to (1) the presence of natural solute via dissolution of soils and weathering; and (2) discharge from industrial

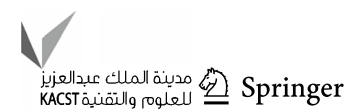


Table 1 Data of physico-chemical properties of groundwater examined in sample locations and previous studies

\begin{tabular}{|c|c|c|c|c|c|c|c|}
\hline \multirow{2}{*}{$\begin{array}{l}\text { Physico-chemical proper- } \\
\text { ties }\end{array}$} & \multicolumn{4}{|c|}{ Sample locations } & \multirow{2}{*}{$\begin{array}{l}\text { The WHO } \\
\text { permissible } \\
\text { range }\end{array}$} & \multirow[t]{2}{*}{ Previous studies } & \multirow[t]{2}{*}{ References } \\
\hline & IW1 & IW2 & RW1 & RW2 & & & \\
\hline $\mathrm{pH}$ & $7.58 \pm 0.06$ & $8.31 \pm 0.02$ & $6.35 \pm 0.15$ & $6.46 \pm 0.05$ & $6.5-8.0$ & $\begin{array}{l}6.10-6.97 \\
5.80-7.50 \\
5.57-8.00\end{array}$ & $\begin{array}{l}\text { Oyem et al. (2014) } \\
\text { Edwin et al. (2015) } \\
\text { Ayodeji et al. (2017) }\end{array}$ \\
\hline TDS (mg/L) & 559.2 & 589.7 & 319.5 & 247.5 & 500.0 & $\begin{array}{l}390-1756.67 \\
166-184 \\
450-1350\end{array}$ & $\begin{array}{l}\text { Behailu et al. (2017) } \\
\text { Ezeribe et al. (2012) } \\
\text { Buridi and Gedala (2014) }\end{array}$ \\
\hline $\mathrm{EC}(\mu \mathrm{S} / \mathrm{cm})$ & 1190.0 & 550.0 & 890.0 & 450.0 & 900.0 & $\begin{array}{l}42.69-320 \\
333-1572 \\
566.33-627.33\end{array}$ & $\begin{array}{l}\text { Okoro et al. (2012) } \\
\text { Ikeme et al. (2014) } \\
\text { Shigut et al. (2017) }\end{array}$ \\
\hline BOD (mg/L) & 1.20 & 1.80 & 4.30 & 2.90 & 10.0 & $\begin{array}{l}4.70-8.90 \\
1.60-5.0 \\
5.90-9.0\end{array}$ & $\begin{array}{l}\text { Obi and Okocha (2007) } \\
\text { Adefemi and Awokunmi } \\
\text { (2010) } \\
\text { Amanial (2015) }\end{array}$ \\
\hline COD (mg/L) & 2.0 & 4.0 & 11.0 & 7.0 & 40.0 & $\begin{array}{l}51.0-93.0 \\
37.0-49.0 \\
7.0-28.0\end{array}$ & $\begin{array}{l}\text { Oyem et al. (2014) } \\
\text { Patil and Patil (2010) } \\
\text { Eid (2017) }\end{array}$ \\
\hline Chloride (mg/L) & 88.60 & 63.90 & 52.20 & 77.40 & 600.0 & $\begin{array}{l}18.40-82.10 \\
73.50-89.30\end{array}$ & $\begin{array}{l}\text { Ezeribe et al. (2012) } \\
\text { Mohammed and Nur (2013) }\end{array}$ \\
\hline Nitrate (mg/L) & 2.37 & 0.52 & 0.33 & 0.81 & 5.0 & $\begin{array}{l}9.78-24.20 \\
3.20-6.40\end{array}$ & $\begin{array}{l}\text { Ezeribe et al. (2012) } \\
\text { Mohsin et al. (2013) }\end{array}$ \\
\hline Sulphate (mg/L) & 63.0 & 50.0 & 16.0 & 13.0 & 400.0 & $\begin{array}{l}23.30-37.90 \\
8.04-24.0\end{array}$ & $\begin{array}{l}\text { Farrukh and Qureshi (2004) } \\
\text { Ezeribe et al. (2012) }\end{array}$ \\
\hline Copper (mg/L) & 0.44 & 0.42 & 0.18 & 0.26 & 1.0 & $\begin{array}{l}0.012-0.176 \\
0.26-0.38\end{array}$ & $\begin{array}{l}\text { Behailu et al. (2017) } \\
\text { Adefemi and Awokunmi } \\
\quad(2010)\end{array}$ \\
\hline Zinc (mg/L) & 0.471 & 0.211 & 0.182 & 0.911 & 15.0 & $\begin{array}{l}0.001-1.054 \\
5.692-12.421\end{array}$ & $\begin{array}{l}\text { Birke et al. (2010) } \\
\text { Fakayode (2005) }\end{array}$ \\
\hline Lead (mg/L) & 0.374 & 0.082 & 0.082 & 0.123 & 0.01 & $\begin{array}{l}0.071-0.122 \\
0.068-0.103\end{array}$ & $\begin{array}{l}\text { Faisal et al. (2014) } \\
\text { Saddozai et al. (2009) }\end{array}$ \\
\hline Manganese (mg/L) & 0.119 & 0.079 & 0.278 & 0.481 & 0.05 & $\begin{array}{l}0.002-0.078 \\
0.083-0.098 \\
0.116-0.361 \\
0.093-0.205\end{array}$ & $\begin{array}{l}\text { Behailu et al. (2017) } \\
\text { Adeyeye (1994) } \\
\text { Laluraj and Gopinath (2006) } \\
\text { Farrukh and Qureshi (2004) }\end{array}$ \\
\hline Iron (mg/L) & 5.26 & 1.60 & 4.71 & 2.20 & 0.30 & $\begin{array}{l}4.84-7.45 \\
0.26-1.37\end{array}$ & $\begin{array}{l}\text { Behailu et al. (2017) } \\
\text { Eruola and Adedokun (2012) }\end{array}$ \\
\hline Cobalt (mg/L) & 0.073 & 0.067 & 0.018 & 0.018 & - & $\begin{array}{l}0.237-0.289 \\
\text { N/A }\end{array}$ & $\begin{array}{l}\text { Khan et al. (2012) } \\
\text { Imam (2012) }\end{array}$ \\
\hline Cadmium (mg/L) & 0.0021 & 0.0025 & 0.001 & 0.000 & 0.003 & $\begin{array}{l}0.013-0.026 \\
\text { N/A } \\
\text { N/A } \\
0.001-0.002\end{array}$ & $\begin{array}{l}\text { Shigut et al. (2017) } \\
\text { Tiwari et al. (2015) } \\
\text { Sumant et al. (2015) } \\
\text { Eruola and Adedokun (2012) }\end{array}$ \\
\hline Chromium (mg/L) & 0.000 & 0.0014 & 0.000 & 0.0022 & 0.05 & $\begin{array}{l}0.014-0.018 \\
\text { N/A } \\
\text { N/A }\end{array}$ & $\begin{array}{l}\text { Buridi and Gedala (2014) } \\
\text { Saleem et al. (2012) } \\
\text { Oguntona et al. (2012) }\end{array}$ \\
\hline
\end{tabular}

treatment plants causing soil contamination leaching and point-source groundwater pollution (Boyd 1999). Implications of high TDS are: (1) organoleptism in human and; (2) reduction in performance of pipes, filters and valves due to scale accumulation (Atekwanaa et al. 2004).

EC is directly related to TDS as it measures ionic content of water sample which determines its ability to conduct 
an electric current. As TDS concentration of water sample increases, the ionic strength also increases. The values of EC obtained for IW1, IW2, RW1 and RW2 were 1190, 550, 890 and $450 \mu \mathrm{S} / \mathrm{cm}$, respectively, as presented in Table 1 . All values obtained were below the permissible value of 1000 $\mu \mathrm{S} / \mathrm{cm}$ specified by the NSDWQ and $900 \mu \mathrm{S} / \mathrm{cm}$ specified by the WHO for drinking water except IW1. The intolerable EC value exhibited by IW1 could be attributed to (1) dissolution of ionic heavy metals from industrial activities of heavy machines which later found their ways into groundwater via leaching of sub-soil layers (Eruola and Adedokun 2012); and (2) higher temperature of the location enhancing movement of ions under electrostatic potential (Oguntona et al. 2012). The side effects are mainly corrosiveness of water and presence of heavy metals that make the water unsuitable for drinking.

\section{Biological and chemical oxygen demands (BOD and COD)}

COD measures oxygen requirement for organic matter chemical oxidation to take place via assistance of strong chemical oxidant, while BOD gives a measure of oxygen requirement for biodegradation of carbonaceous matter in a sample. The values revealed by IW1, IW2, RW1 and RW2 for COD and BOD were 2, 4, 11 and $7 \mathrm{mg} / \mathrm{L}$; and 1.2, 1.8, 4.7 and $2.9 \mathrm{mg} / \mathrm{L}$, as presented in Table 1 . All values were below the maximum permissible values of 40 and $10 \mathrm{mg} / \mathrm{L}$ specified for COD and BOD, respectively, by the WHO and make them suitable for domestic usage. IW1 revealed minimum COD and BOD, while RW1 revealed maximum COD and BOD levels. This is due to sufficiently large volume of municipal and solid wastes generated within the densely populated region, transported into the ground via leaching, constituting to water pollution by increasing the organic content amount (Sumant et al. 2015). Thus, more oxygen is required by the microbes for their degradation.

\section{Chloride $\left(\mathrm{Cl}^{-}\right)$}

Concentration of chloride varies from types of water and has been found to exist naturally in the form of sodium and potassium salts. It is a stable water component whose concentration is uninterrupted by both bio- and physico-chemical processes. As shown in Table 1, the concentration of chloride ranges from 52.2 to $88.6 \mathrm{mg} / \mathrm{L}$ with RW1 and IW1 having the lowest and highest concentrations. All measured concentrations were below the maximum permissible values of 250 and $600 \mathrm{mg} / \mathrm{L}$ specified by the NSDWQ and the WHO, respectively. The presence of chlorides could be due to (1) chloride-containing soils and rocks undergoing leaching which later got in contact with underground water for all examined locations (Aremu et al. 2011), (2) high chloride-rich sewage and municipal effluents discharged by residents in examined locations for RW1 and RW2 which later found its way into underground water (Gorde and Jadhav 2013) and (3) chloride salts used as essential ingredients for confectionaries production discharged as industrial effluents in investigated locations for IW1 and IW2. Chlorides have been investigated as essential ingredient for activities involving human body metabolism (Mohsin et al. 2013).

However, excessive chlorides concentration in water could lead to (1) laxative effect, (2) metallic pipes damage and (3) unsuitability of water for agricultural irrigation (Raviprakash and Krishna 1989).

\section{Nitrate $\left(\mathrm{NO}_{3}{ }^{-}\right)$}

The results obtained revealed nitrate content with minimum and maximum concentrations of 0.33 and $2.37 \mathrm{mg} / \mathrm{L}$ for RW1 and IW1, respectively, as presented in Table 1 . All measured values were below the WHO permissible value $(5 \mathrm{mg} / \mathrm{L})$. However, a fertilizer company located at about $4 \mathrm{~km}$ away from sample location IW1 could have contributed to the nitrate concentration in the sample. Highly concentrated wastes containing nitrogen compounds could have been oxidized to nitrate when discharged into the environment and found its way into groundwater via percolation. Major health implications of excess nitrate in water are hypertension in adults (Mkadmi et al. 2018) and methaemoglobinaemia in infants (Bruning-Fann and Kanaeme 1993).

\section{Sulphate $\left(\mathrm{SO}_{4}{ }^{2-}\right)$}

Sulphates are oxidation results of (1) their ores and (2) $\mathrm{H}_{2} \mathrm{~S}$ by some bacteria activities such as chlorothiobacteria and rhodothiobacteria. Their ions exist naturally in water with little or no health implications recorded so far. The respective sulphate concentrations obtained for IW1, IW2, RW1 and RW2 were 63, 50, 16 and $13 \mathrm{mg} / \mathrm{L}$, as presented in Table 1 . The minimum concentration of $13 \mathrm{mg} / \mathrm{L}$ was revealed by water sample taken at location RW2, while maximum concentration of $63 \mathrm{mg} / \mathrm{L}$ was obtained for water sample taken at location IW1. All values were below the WHO, NSDWQ, EPA and IS 10500-2012 permissible values of $400,100,250$ and $200 \mathrm{mg} / \mathrm{L}$, respectively. However, accumulation of sulphate in water may lead to increase in water $\mathrm{pH}$ causing acidosis (Asamoah and Amorin 2011). No other health implication and side effects have been recorded so far for excess sulphate in water.

\section{Heavy metals}

\section{Copper}

From the result presented in Table 1, the minimum and maximum copper concentrations of $0.18 \mathrm{mg} / \mathrm{L}$ and $0.44 \mathrm{mg} / \mathrm{L}$ 
were exhibited by RW1 and IW1, respectively. However, all values obtained were below the permissible concentration of $1 \mathrm{mg} / \mathrm{L}$ specified by the NSDWQ and the WHO. When excess copper is present in water (above the permissible level), gastrointestinal disorder occurs after a long period of exposure.

\section{Zinc}

Research has recorded approximately $0.05 \mathrm{~g} / \mathrm{kg}$ of zinc to be present naturally in the earth crust (Dohare et al. 2014). From the study areas, the maximum and minimum zinc levels were $0.911 \mathrm{mg} / \mathrm{L}$ (RW2) and $0.182 \mathrm{mg} / \mathrm{L}$ (RW1) (Table 1). All examined samples revealed zinc concentration below the permissible standard values of 3,5 and $15 \mathrm{mg} / \mathrm{L}$ set by the NSDWQ, IS 10500-2012 and the WHO, respectively. This could be that the zinc in its natural mineral form (sphalerite) did not dissolve into underground water bodies via leaching in all examined locations (Broadly et al. 2007). However, medical experts have reported electrolyte imbalance, vomiting, acute renal failures and abdominal pain as symptoms of excessive exposure of human to zinc.

\section{Lead}

Of all heavy metals, lead is the most significant due to its toxic and harmful instinct even at very small concentrations (Gregoriadou et al. 2001). It can accumulate in body tissue posing threat to human health. From the examined samples at different locations, concentration of lead ranges from minimum and maximum concentrations of $0.082 \mathrm{mg} / \mathrm{L}$ (IW2 and RW1) and $0.374 \mathrm{mg} / \mathrm{L}$ (IW1), respectively (Table 1). Lead concentrations of all samples were above the permissible value of $0.01 \mathrm{mg} / \mathrm{L}$ indicated by the WHO and NSDWQ. Due to the toxic nature of lead, EPA permissible level is zero $\mathrm{mg} / \mathrm{L}$.

High concentrations of lead in samples located at IW1 and IW2 could be attributed to (1) discharge of lead-rich waste effluents from nearby paint industry deposited in the soil which later found its way into underground water via leaching and (2) dissolution by heavy rain of emitted aerosols and dusts into the soil from industrial heavy plants which are transported by wind. The major influence of high lead concentrations in water samples from RW1 and RW2 could be from (1) leaching of natural deposits of lead ores in the soil into the groundwater (Imam 2012), (2) higher volume of leaded gasoline exhausts from motor vehicles in the residential area and (3) reaction of water with removed coated-lead from pipe's surface due to turbulent motion of transporting water from ground level to surface level.

The presence of lead in water beyond the permissible level could result in hypertension, interference with Vitamin D and calcium metabolism, brain development hindrance in foetus and young children, damage to tissues and organs in human and many more.

\section{Manganese}

Manganese is ores and rocks constituent which is widely distributed naturally. It is a vital element for biological systems whose chemical behaviour is a function of $\mathrm{pH}$, oxidation and reduction reactions (Shand et al. 2007). The concentration of manganese in examined samples ranged from $0.079 \mathrm{mg} / \mathrm{L}$ (IW2) to $0.481 \mathrm{mg} / \mathrm{L}$ (RW2) (Table 1). All water samples exhibited manganese concentration above the permissible value of $0.05 \mathrm{mg} / \mathrm{L}$ specified by the WHO. This observation could be due to (1) groundwater contact with dissolved soil, rock and minerals of manganese in the aquifer for all sample locations, (2) leaching of industrial effluents discharge into the soil for sample locations IW1 and IW2 and (3) leachate from landfill and sewage deposited over time in residential locations for RW1 and RW2. Effects of high manganese concentration in water include (1) metallic and unpleasant taste to water, (2) blackish staining of laundry and plumbing fixtures and (3) formation of darkish scales in water pipes (Takeda 2003). However, no record of excess manganese health risk has been recorded in humans.

\section{Iron}

Like manganese, iron exists in its natural form as ores (magnetite, taconite and haematite) in rocks, soil and minerals making about 5\% of the Earth's crust (Colter and Mahler 2006). It is dark-grey in colouration when in pure form and exists in groundwater as ferric hydroxide. The minimum and maximum iron concentrations of 0.15 and $3.26 \mathrm{mg} / \mathrm{L}$ were observed in RW2 and IW1, respectively (Table 1). From the analysed samples, two of the samples (IW1 and RW1) have Fe concentrations above the permissible WHO, EPA, NSDWQ and IS 10500-2012 standard value of $0.3 \mathrm{mg} / \mathrm{L}$ with the maximum concentration level revealed by water sample collected from location IW1. The observed Fe concentration above the permissible level could be linked to (1) weathering of minerals and rocks (mineralogical and piezometry features) of iron in the soil for the examined locations (IW1 and RW1) and (2) dissolution of iron natural deposits into groundwater bodies via leaching. However, anaemia has been reported as a result of iron shortage in humans. Results of extensive consumption of drinking water containing high $\mathrm{Fe}$ concentration level are haemosiderosis (liver-damage disease), diabetes mellitus, arteriosclerosis and many other neurodegenerative diseases (Nagendrappa et al. 2010; Brewer 2009). 


\section{Cobalt}

Cobalt can hardly be found in its native state but exists in sulphide and arsenide form as minerals which are linnaeite $\left(\mathrm{Co}_{3} \mathrm{~S}_{4}\right)$, cobaltite (CoAsS), carrollite $\left(\mathrm{CuCo}_{2} \mathrm{~S}_{4}\right)$ and smaltite $\left(\mathrm{CoAs}_{2}\right)$ (Turekian and Scott 1994). In the examined sample locations, respective minimum and maximum Co concentrations were $0.018 \mathrm{mg} / \mathrm{L}$ (RW1) and $0.073 \mathrm{mg} / \mathrm{L}$ (IW1) (Table 1). The presence of cobalt could be attributed to heavy metals presence in industrial waste effluent discharges (for IW1 and IW2), while the presence in all samples could result from leached minerals of cobalt present in the soil into underground water. No permissible concentration of cobalt has been specified by the WHO and some global agencies. It plays a key role in the synthesis of vitamin B-12 which is an essential vitamin in the human body. However, people exposed to high concentration of cobalt have been reported to have lung diseases such as wheezing, asthma and pneumonia (Chaney 1982).

\section{Cadmium}

Cadmium exists as (1) natural ores in rocks and soils, and (2) zinc refining by-product (Wang et al. 2006). The presence of cadmium in groundwater occurred via leaching when in contact with soil contaminated with discharges from mining, paints, electroplating, petrochemical, plastics and fertilizer industries (DeZuane 1997). Out of the examined samples from different locations, only three (IW1, IW2 and RW1) exhibited the presence of $\mathrm{Cd}$ with the minimum concentration of $0.001 \mathrm{mg} / \mathrm{L}$ (RW1) and the maximum concentration of $0.0025 \mathrm{mg} / \mathrm{L}$ (IW2), as presented in Table 1 . Though $\mathrm{Cd}$ concentrations were below the permissible value $(0.003 \mathrm{mg} / \mathrm{L})$ specified by the WHO and NSDWQ, epidemiological studies have shown that long-term exposure to Cd could cause (1) kidney damage, (2) lung cancer, (3) high blood pressure and (4) bone defects (osteoporosis and osteomalacia). The presence of cadmium in examined samples could be attributed to (1) leaching of waste runoff from battery industry located at about $2.5 \mathrm{~km}$ away from sample location (IW1) into the soil, (2) leaching of waste discharge from paint industry located few kilometres away from the sample location (IW2) and (3) galvanized steel pipe corrosion used in conveying water from the ground level to surface level (RW1) (El-Harouny et al. 2009).

\section{Chromium}

Chromium exists naturally as element in rocks, soil, plants, animals and volcano emissions. It is found in drinking water in trivalent (chromium 3) and hexavalent (chromium 6) principal forms. Only IW2 and RW2 exhibited minimum and maximum Cr concentrations of $0.0014 \mathrm{mg} / \mathrm{L}$ and
$0.0022 \mathrm{mg} / \mathrm{L}$, respectively (Table 1). Natural deposits erosion and coatings removal from water pipes could have been the major causatives of $\mathrm{Cr}$ presence in groundwater samples. Though $\mathrm{Cr}$ concentrations were below the WHO and NSDWQ permissible value of $0.05 \mathrm{mg} / \mathrm{L}$, health implications of excessive exposure to chromium are as stated for cadmium.

\section{Statistical correlation of groundwater contaminants}

Pearson's correlation $(r)$ reveals existing interaction between minimum of two continuous variables with values ranging between -1 and +1 . This statistical tool was used to correlate groundwater contaminants in examined locations. A negative value implies negative correlation, while a positive value implies positive correlation between variables. A value of $r=0$ is an indication of negligible connection between parameters. In most cases, strong correlation exists within parameters when $r^{>} 0.7$, while moderate correlation exists when $r$ ranges between 0.5 and 0.7 (Saleem et al. 2012). Table 2 presents the Pearson's correlation results of physicochemical parameters of assessed water samples. The result revealed approximately $32 \%, 10 \%$ and $58 \%$ of the physicochemical parameters to be strongly $(r \geq 0.7)$, moderately $(0.5$ $\left.<r^{<} 0.7\right)$ and poorly $\left(r^{<} 0.5\right)$ correlated. At $p^{<} 0.05$, parameters that correlated positively with one another include: TDS with $\mathrm{pH}(r=0.894)$ and $\mathrm{Cu}(r=0.805) ; \mathrm{pH}$ with $\mathrm{Cu}$ $(r=0.818)$, $\mathrm{Co}(r=0.843)$ and $\mathrm{Cd}(r=0.812)$; EC with $\mathrm{Fe}$ $(r=0.878)$ and $\mathrm{Cr}(r=0.842)$; COD with $\mathrm{Co}(r=0.808)$; BOD with $\mathrm{Co}(r=0.8133) ; \mathrm{SO}_{4}{ }^{-}$with $\mathrm{Cu}(r=0.886) ; \mathrm{Fe}$ with $\mathrm{Cr}(0.805)$ and lastly Co with $\mathrm{Cd}(r=0.821)$. At $p^{<}$ 0.01 , parameters that strongly correlated with one another include: TDS with $\mathrm{Co}(r=0.947)$ and $\mathrm{Cd}(r=0.956)$; COD with BOD $(r=0.999)$ and $\mathrm{Cu}(r=0.949)$; BOD with $\mathrm{Cu}$ $(r=0.956) ; \mathrm{NO}_{3}{ }^{-}$with $\mathrm{PO}_{4}{ }^{-}(r=0.908)$ and $\mathrm{Pb}(r=0.990)$; $\mathrm{SO}_{4}{ }^{-}$with $\mathrm{Co}(r=0.980) ; \mathrm{PO}_{4}{ }^{-}$with $\mathrm{Pb}(r=0.926)$; $\mathrm{Cu}$ with Co $(r=0.932)$; and lastly Mn with Cd $(r=0.987)$. Though none of the remaining parameters was negatively correlated, they were poorly significantly correlated with $\mathrm{r}$ values of less than 0.7 at $p^{<} 0.05$ or $<0.01$. However, majority of the measured physico-chemical parameters correlated with one another at either $p^{<} 0.05$ or ${ }^{<} 0.01$ which is an indication that availability of specified pollution indicators will definitely have an influence on other assessed pollutants in water samples located at both industrial (IW1 and IW2) and residential (RW1 and RW2) locations.

\section{Conclusion}

The present study examined groundwater samples from two different industrial and residential locations of Lagos metropolis for some selected physico-chemical parameters

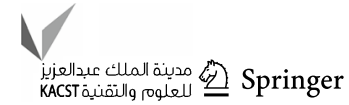


Table 2 Pearson's correlation of physico-chemical parameters of water samples

\begin{tabular}{|c|c|c|c|c|c|c|c|c|c|c|c|c|c|c|c|c|c|}
\hline & TDS & $\mathrm{pH}$ & $\mathrm{EC}$ & COD & BOD & $\mathrm{Cl}^{-}$ & $\mathrm{NO}_{3}^{-}$ & $\mathrm{SO}_{4}^{-}$ & $\mathrm{PO}_{4}^{-}$ & $\mathrm{Cu}$ & $\mathrm{Zn}$ & $\mathrm{Pb}$ & $\mathrm{Mn}$ & $\mathrm{Fe}$ & $\mathrm{Co}$ & $\mathrm{Cd}$ & $\mathrm{Cr}$ \\
\hline TDS & 1.00 & & & & & & & & & & & & & & & & \\
\hline $\mathrm{pH}$ & 0.894 & 1.00 & & & & & & & & & & & & & & & \\
\hline EC & 0.138 & 0.003 & 1.00 & & & & & & & & & & & & & & \\
\hline COD & 0.612 & 0.627 & 0.059 & 1.00 & & & & & & & & & & & & & \\
\hline BOD & 0.623 & 0.649 & 0.049 & 0.999 & 1.00 & & & & & & & & & & & & \\
\hline $\mathrm{Cl}^{-}$ & 0.063 & 0.050 & 0.084 & 0.597 & 0.574 & 1.00 & & & & & & & & & & & \\
\hline $\mathrm{NO}_{3}^{-}$ & 0.192 & 0.071 & 0.494 & 0.545 & 0.516 & 0.775 & 1.00 & & & & & & & & & & \\
\hline $\mathrm{SO}_{4}^{-}$ & 0.905 & 0.729 & 0.276 & 0.787 & 0.785 & 0.261 & 0.481 & 1.00 & & & & & & & & & \\
\hline $\mathrm{PO}_{4}^{-}$ & 0.026 & 0.001 & 0.522 & 0.262 & 0.237 & 0.698 & 0.908 & 0.205 & 1.00 & & & & & & & & \\
\hline $\mathrm{Cu}$ & 0.805 & 0.818 & 0.059 & 0.949 & 0.956 & 0.374 & 0.398 & 0.886 & 0.135 & 1.00 & & & & & & & \\
\hline $\mathrm{Zn}$ & 0.270 & 0.153 & 0.120 & 0.015 & 0.013 & 0.392 & 0.063 & 0.102 & 0.137 & 0.008 & 1.00 & & & & & & \\
\hline $\mathrm{Pb}$ & 0.180 & 0.051 & 0.593 & 0.466 & 0.437 & 0.693 & 0.990 & 0.460 & 0.926 & 0.340 & 0.036 & 1.00 & & & & & \\
\hline $\mathrm{Mn}$ & 0.913 & 0.716 & 0.226 & 0.332 & 0.339 & 0.003 & 0.098 & 0.754 & 0.005 & 0.534 & 0.547 & 0.107 & 1.00 & & & & \\
\hline $\mathrm{Fe}$ & 0.001 & 0.088 & 0.878 & 0.005 & 0.009 & 0.024 & 0.299 & 0.039 & 0.449 & 0.010 & 0.056 & 0.395 & 0.031 & 1.00 & & & \\
\hline Co & 0.947 & 0.843 & 0.163 & 0.808 & 0.813 & 0.219 & 0.369 & 0.980 & 0.118 & 0.932 & 0.106 & 0.340 & 0.768 & 0.004 & 1.00 & & \\
\hline $\mathrm{Cd}$ & 0.956 & 0.812 & 0.157 & 0.402 & 0.412 & 0.003 & 0.094 & 0.784 & 0.002 & 0.615 & 0.474 & 0.096 & 0.987 & 0.006 & 0.821 & 1.00 & \\
\hline $\mathrm{Cr}$ & 0.097 & 0.002 & 0.842 & 0.002 & 0.004 & 0.013 & 0.135 & 0.129 & 0.157 & 0.005 & 0.405 & 0.208 & 0.265 & 0.805 & 0.065 & 0.174 & 1.00 \\
\hline
\end{tabular}

Significant correlation at 0.01 and 0.05 levels are in bold

which include $\mathrm{pH}$, TDS, EC, BOD, $\mathrm{COD}, \mathrm{Cl}^{-}, \mathrm{NO}_{3}{ }^{-}, \mathrm{SO}_{4}{ }^{2-}$, $\mathrm{Cu}, \mathrm{Zn}, \mathrm{Pb}, \mathrm{Mn}, \mathrm{Fe}, \mathrm{Co}, \mathrm{Cd}$ and $\mathrm{Cr}$ with respective mean values of $7.175 \pm 0.07,428.975 \mathrm{mg} / \mathrm{L}, 770 \mu \mathrm{S} / \mathrm{cm}, 2.55 \mathrm{mg} / \mathrm{L}$, $6 \mathrm{mg} / \mathrm{L}, 70.525 \mathrm{mg} / \mathrm{L}, 1.008 \mathrm{mg} / \mathrm{L}, 0.325 \mathrm{mg} / \mathrm{L}, 0.444 \mathrm{mg} / \mathrm{L}$, $0.165 \mathrm{mg} / \mathrm{L}, 0.239 \mathrm{mg} / \mathrm{L}, 3.443 \mathrm{mg} / \mathrm{L}, 0.044 \mathrm{mg} / \mathrm{L}$, $0.0014 \mathrm{mg} / \mathrm{L}$ and $0.0009 \mathrm{mg} / \mathrm{L}$. From the executed laboratory analysis for groundwater samples from industrial locations, all measured values of physico-chemical parameters were either below permissible values or within ranges specified by the Nigerian Standard for Drinking Water Quality and the World Health Organization except pH, TDS, EC, $\mathrm{Pb}, \mathrm{Mn}$ and $\mathrm{Fe}$, while only $\mathrm{pH}, \mathrm{Pb}, \mathrm{Mn}$ and $\mathrm{Fe}$ violated permissible values for groundwater samples collected from residential locations. From the result obtained, higher concentrations of TDS and EC were reported for groundwater samples collected from industrial locations than those from residential locations due to heavy discharge of effluents from industrial treatment plants as well as dissolution of ionic heavy metals from industrial activities of heavy machines. In conclusion, various industrial and residential activities have influence on the parameters of water quality examined. Also, the statistical Pearson's correlation result revealed measured physico-chemical parameters to be moderately and strongly correlated with one another at either $p^{<} 0.05$ or $<0.01$.

\section{Recommendation}

Blood samples of residents drinking samples of groundwater collected from locations should be examined for future research work to know the levels of $\mathrm{Pb}, \mathrm{Mn}$ and $\mathrm{Fe}$ in their blood streams. This will enable them to know their health status in this regard and also help medical experts in the field to recommend drugs if need be for residents exposed to excess concentrations of these heavy metals. Government of Lagos should be strict with industrial laws guiding waste disposal and treatment from industries as this is a major contributor to increase in concentrations of heavy metal in groundwater. Also, industrial activities contributing to this should be checked and controlled. Nonetheless, there should be consistent enlightenment to residents on proper waste disposal techniques as decays from these are also major contributors.

Open Access This article is distributed under the terms of the Creative Commons Attribution 4.0 International License (http://creativeco mmons.org/licenses/by/4.0/), which permits unrestricted use, distribution, and reproduction in any medium, provided you give appropriate credit to the original author(s) and the source, provide a link to the Creative Commons license, and indicate if changes were made.

\section{References}

Adefemi SO, Awokunmi EE (2010) Determination of physico-chemical parameters and heavy metals in water samples from Itaogbolu area of Ondo-State, Nigeria. Afr J Environ Sci Technol 4(3):145-148

Adewolu MA, Akintola SL, Jimoh AA, Owodehinde FG, Whenu OO, Fakoya KA (2009) Environmental threats to the development of aquaculture in Lagos State, Nigeria. Eur J Sci Res 34(3):337-347

Adeyeye EL (1994) Determination of heavy metals in Illisha Africana, associated water, soil sediments from some fish ponds. Int J Environ Study 45:231-240 
Akinlalu AA, Afolabi DO (2018) Borehole depth determination to freshwater and well design using geophysical logs in coastal regions of Lagos, southwestern Nigeria. Appl Water Sci 8:152

Amanial HR (2015) Assessment of physicochemical quality of spring water in Arbaminch, Ethiopia. J Environ Anal Chem 2:157-163

APHA (2012) Standard methods for the examination of water, 22nd edn. American Public Health Association, Washington

Aremu MO, Olaofe O, Ikokoh PP, Yakubu MM (2011) Physicochemical characteristics of stream, well and borehole water sources in Eggon, Nasarawa State, Nigeria. J Chem Soc Niger 36(1):131-136

Asamoah AA, Amorin BS (2011) Assessment of the quality of bottled sachet water in the Tarkwa-Nsuaem municipality in Ghana. Res J Appl Sci 3(5):105-113

Atekwanaa EA, Atekwanaa EA, Roweb RS, Werkema DD, Legalld FD (2004) The relationship of total dissolved solids measurements to bulk electrical conductivity in an aquifer contaminated with hydrocarbon. J Appl Geophys 56(4):281-294

Ayodeji AS, Abubakar S, Samuel E (2017) Physicochemical analysis of underground water in Zaria Metropolis, Kaduna State, Nigeria. Am J Chem Eng 5(6):158-162

Behailu TW, Badessa TS, Tewodros BA (2017) Analysis of physical and chemical parameters in groundwater used for drinking around Konso area, Southwestern Ethiopia. J Anal Bioanal Tech 8(5):1-7. https://doi.org/10.4172/2155-9872.1000379

Birke M, Reimann C, Demetriades A, Rauch U, Lorenz H (2010) Determination of major and trace elements in European bottled mineral water-analytical methods. J Geochem Explor 107:217-226

Boyd CE (1999) Water quality: an introduction. Kluwer Academic Publishers Group, Dordrecht. ISBN 0-7923-7853-9

Brewer G (2009) Risks of copper and iron toxicity during aging in humans. Chem Res Toxicol 2:319-326

Broadly MR, White PJ, Hammond HP, Zelko I, Lux A (2007) Zinc in plant. New Phytol 173(4):677-702

Bruning-Fann CS, Kanaeme JB (1993) The effect of nitrate, nitrite, and $\mathrm{N}$-nitro compound on human health. Vet Hum Toxicol 35:521-538

Buridi KR, Gedala RK (2014) Study on determination of physicochemical parameters of groundwater in industrial area of pydibheemavaram, Vizianagaram District, Andhrapradesh, India. Austin J Public Health Epidemiol 1(2):1-2

Chaney RL (1982) Fate of toxic substances in sludge applied to crop land. In: Proceedings of an international symposium on land application of Sewage Sludge, Tokyo, Japan

Colter AJ, Mahler BG (2006) Iron in drinking water. University of Idaho, Moscow

DeZuane J (1997) Handbook of drinking water quality. Wiley, Hoboken

Dissmeyer GE (2000) Drinking water from Forests and Grasslands, South Research Station, USDA Forest Service, Ashville, NC, USA

Dohare D, Deshpande S, Kotiya A (2014) Analysis of groundwater quality parameters: a review. Res J Eng Sci 3(5):26-31

Duan B, Liu F, Zhang W, Zheng H, Zhang Q, Li X, Bu Y (2015) Evaluation and source apportionment of heavy metals (HMs) in Sewage sludge of municipal wastewater treatment plants (WWTPs) in Shanxi, China. Int J Environ Res Public Health 12:15807-15818. https://doi.org/10.3390/ijerph121215022

Edwin N, Ibiam UA, Igwenyi IO, Ude VC, Eko SN (2015) Evaluation of physicochemical properties, mineral and heavy metal content of drinking water samples in two communities in South-East, Nigeria: a puplic health implication. J Environ Earth Sci 5(9):89-94

Eid BI (2017) Physicochemical properties and the concentration of anions, major and trace elements in groundwater, treated drinking water and bottled drinking water in Najran area, KSA. Appl Water Sci 7:401-410

El-Harouny M, El-Dakroory S, Attalla S, Hasan N, Hegazy R (2009) Chemical quality of tap water versus bottled water: evaluation of some heavy metals and elements content of drinking water in Dakhlia Governorate-Egypt. Int J Nutr Wellness 9(2):23-29

Eruola AO, Adedokun NA (2012) Analytical assessment of cadmium, lead and iron in hand dug wells of Ilaro, South Western Nigeria. Glob J Sci Front Res Chem 12(6):23-29

Ezeribe AI, Oshieke KC, Jauro A (2012) Physico-chemical properties of well water samples from some villages in Nigeria with cases of stained and mottle teeth. Sci World J 7(1):1-3

Faisal BMR, Majumder RK, Uddin MJ, Halim MA (2014) Studies on heavy metals in industrial effluent, river and groundwater of Savar industrial area, Bangladesh by principal component analysis. Int J Geomat Geosci 5(1):182-191

Fakayode SO (2005) Impact of industrial effluents on water quality of the receiving Alaro River in Ibadan, Nigeria. Ajeam Ragee 10:1-13

Farrukh RH, Qureshi NA (2004) Assessment of drinking water quality of a coastal village of Karachi. Pak J Sci Ind Res 47(5):370-375

Gorde SP, Jadhav MV (2013) Assessment of water quality parameters: a review. J Eng Res Appl 3(6):2029-2035

Gregoriadou A, Delidou K, Dermosonoglou D, Tsoum PP, Edipidi C, Katsougiannopoulos B (2001) Heavy metals in drinking water in Thessaloniki area, Greece. In: Proceedings of the 7th international conference on environmental hazards mitigation, Cairo University, Egypt, pp 542-556

Heydari MM, Bidgoli HN (2012) Chemical analysis of drinking water of Kashan District, Central Iran. World Appl Sci J 16(6):799-805

Ikeme CH, Dioha IJ, Olasusi KA, Chukwu PU (2014) Physico-chemical analysis of selected borehole water In Umuihi, Town Imo State, Nigeria. Int J Sci Eng Res 5(8):680-689

Imam TS (2012) Assessment of heavy metal concentrations in the surface water of Bompai-Jakara Drainage Basin, Kano State, Northern Nigeria. Bayero J Pure Appl Sci 5(1):103-108

Khan N, Hussain ST, Hussain J, Jamila N, Ahmed S, Riaz U, Zain U, Saboor A (2012) Physiochemical evaluation of the drinking water sources from District Kohat, Khyber Pakhtunkhwa, Pakistan. Int J Water Res Environ Eng 4(10):302-313

Lagos State Water Regulatory Commission (2018) Records of borehole in Lagos State, 3rd edn. LSWRC Press, Lagos State

Laluraj CM, Gopinath G (2006) Assessment on seasonal variation of groundwater quality of phreatic aquifers-a river basin system. Environ Monit Assess 117:45-57

Lovelyn NU, Egbulezu AVI, Chudi OPA (2014) Assessment of heavy metal pollution of effluents from three food industries within Onitsha in Anambra State, Nigeria. Int J Environ Monit Anal 2(5):259-265. https://doi.org/10.11648/j.ijema.20140205.15

Meinhardt PL (2006) Recognizing waterborne disease and the health effects of water contamination: a review of the challenges facing the medical community in the United States. J Water Health 4(1):27-34

Mkadmi Y, Benabbi O, Fekhaoui M, Benakkam R, Bjijou W, Elazzouzi M, Kadourri M, Chetouani A (2018) Study of the impact of heavy metals and physico-chemical parameters on the quality of the wells and waters of the Holcim area (Oriental region of Morocco). J Mater Environ Sci 9(2):672-679

Mohammed N, Nur A (2013) Physicochemical analysis of groundwater samples of gwoza town and environs, northeastern Nigeria. Int J Res Earth Environ Sci 1:28-34

Mohsin M, Safdar S, Asghar F, Jamal F (2013) Assessment of drinking water quality and its impact on residents health in Bahawalpur City. Int J Humanit Soc Sci 3(15):114-128

Nagendrappa G, Bhaskar CV, Kumar K (2010) Assessment of heavy metals in water samples of certain locations situated around Tumkur, Karnataka India. E J Chem 7(2):349-352

Obi CN, Okocha CO (2007) Microbiological and physicochemical analysis of selected borehole waters. J Eng Appl Sci 257:920-929

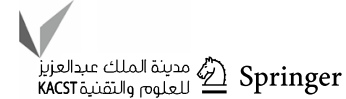


Oguntona TS, Adedeji OO, Martins OC (2012) Contamination of Sachet water produced within industrial area of Ikeja, Lagos Nigeria. Int J Environ Sci 3(2):23-29

Okoro HK, Adeyinka A, Jondiko OE, Ximba BJ (2012) Physico-chemical analysis of selected groundwater samples of Ilorin town in Kwara State, Nigeria. Sci Res Essays 7(23):2063-2069

Oyem HH, Oyem IM, Ezeweali D (2014) Temperature, pH, electrical conductivity, total dissolved solids and chemical oxygen demand of groundwater in Boji-BojiAgbor/Owa area and immediate suburbs. Res J Environ Sci 8(8):444-450

Patil VT, Patil PR (2010) Physicochemical analysis of selected groundwater samples of Amalner Town in Jalgaon District, Maharashtra, India. E J Chem 7(1):111-116

Rahmanian N, Ali SH, Homayoonfard M, Ali NJ, Rehan M, Sadef Y, Nizami AS (2015) Analysis of physiochemical parameters to evaluate the drinking water quality in the state of Perak, Malaysia. J Chem. https://doi.org/10.1155/2015/716125

Raviprakash SL, Krishna RG (1989) The chemistry of groundwater Paravada area with regard to their suitability for domestic and Irrigation purpose. India J Geochem 4(1):39-54

Rose P (1986) Alkaline $\mathrm{pH}$ and health: a review prepared for the Water Research Centre, Medmenham, Water Research Centre, Report No LR 1178-M

Sabhapandit P, Saika P, Mishra AK (2010) Statistical analysis of heavy metals from water samples of Tezpur sub-division in Sonitpur District, Assam, India. Int J Appl Biol Pharm Technol 1(3):946

Saddozai AA, Khalil S, Hameed T (2009) Microbial quality of food snakes and drinking water in islamabad schools and colleges. Pak J Agric Res 22(3-4):144-149

Saleem A, Dandigi MN, Vijay KK (2012) Correlation and regression model for physicochemical quality of groundwater in the South Indian City of Gulbarga. Afr J Environ Sci Technol 6(9):353-364

Shand P, Edmunds WM, Lawrence AR, Smedley PL, Burke S (2007) The natural (baseline) quality of groundwater in England and Wales. British Geological Survey Research Report No. RR/07/06

Shigut DA, Liknew G, Irge DD, Ahmad T (2017) Assessment of physico-chemical quality of borehole and spring water sources supplied to Robe Town, Oromia Region, Ethiopia. Appl Water Sci 7:155-164. https://doi.org/10.1007/s13201-016-0502-4

Standard Organization of Nigeria (2007) Nigerian standard for drinking water quality, hand book, Wuse Zone 7, Abuja, Nigeria

Sumant KNC, Ghosh RP, Singh MM, Sonkusare SS, Sanjay M (2015) Assessment of water quality of lakes for drinking and irrigation purposes in Raipur City, Chhattisgarh, India. IJERA 5:42-49

Takeda A (2003) Manganese actions in brain function. Brain Res Rev 41(1):74-82

Tiwari AK, Singh AK, Singh AK, Singh MP (2015) Hydrogeochemical analysis and evaluation of surface water quality of Pratapgarh District. Appl Water Sci Uttar Pradesh. https://doi.org/10.1007/ s13201-015-0313-z

Turekian KK, Scott M (1994) Concentrations of Cr, Ag, Mo, Ni, Co and $\mathrm{Mn}$ in suspended material in streams. Environ Sci Technol 1(5):940-952

Tuzen M, Soylak M (2006) Evaluation of metal levels of drinking waters from the Tokat-black sea region of Turkey. Pol J Environ Stud 15(6):915-919

Wang G, Su MY, Chen YH, Lin FF, Luo D, Gao SF (2006) Transfer characteristics of cadmium and lead from soil to the edible parts of six vegetable species in southeastern China. Environ Pollut 144:127-135

World Health Organization (2009) Policies and procedures used in updating the WHO guidelines for drinking water quality. Public Health and the Environment World Health Organization Summit, Geneva

World Health Organization (WHO) (2011) Guidelines for drinkingwater quality, 4 th edn. WHO Press, Geneva

World Health Organization Working Group (1986) Health impact of acidic deposition. Sci Total Environ 52:157-187

Publisher's Note Springer Nature remains neutral with regard to jurisdictional claims in published maps and institutional affiliations. 